\title{
Sejmo(gra)
}

\section{Miłosz Socha}

Uniwersytet Łódzki

\begin{abstract}
Abstrakt. Artykuł stanowi próbę analizy przekazu w celu uchwycenia rzeczywistych znaczeń, jakie są konstruowane w trakcie przemówień sejmowych pomiędzy partnerami interakcji. Punktem odniesienia do przeprowadzonej analizy jest socjologia emocji Thomasa Scheffa oraz perspektywa dramaturgiczna Ervinga Goffmana i związane z nią pojęcia: „twarzy”, „występu”, czy „ośmieszenia”. Aby sprostać temu zadaniu, dokonuję analizy treści przemówień, gestów i zachowań, jakie prezentują na mównicy sejmowej premier Donald Tusk i poseł Witold Waszczykowski.
\end{abstract}

Słowa kluczowe: socjologia emocji, polityka, konstruowanie przekazu, wstyd, twarz, symboliczny interakcjonizm, Erving Goffman, Thomas Scheff

W tym zamieszaniu spadty pisma i układy. „Zdrajcy!” krzyczano, lecz, do kogo, trudno rzec. Polityk przecież w ogóle nie zna słowa ,zdrada”,

A politycznych obyczajów trzeba strzec.

Skłócony naród, król niepewny, szlachta dzika Sympatie zmienia wraz z nastrojem raz po raz.

Rozgrywka z nimi to nie żadna polityka, To wychowanie dzieci, biorąc rzecz en masse.

Dlatego radzę: nim ochłona ze zdumienia Ta droga dalej iść, nie grozi niczym to; Wygrać, co da się wygrać! Rzecz nie bez znaczenia, Zanim nastapi europejskie qui pro quo! Jacek Kaczmarski, Rejtan, czyli raport ambasadora ${ }^{1}$

1 Utwór pochodzący z albumu „Muzeum”, Pomaton EMI, 1991. 


\section{Wstęp}

Zanim rozpocznę analizę wystąpień sejmowych, chciałbym pochylić się nad ich szerszym kontekstem, który wykracza poza omawiane przeze mnie przykłady (wystąpienie Donalda Tuska: 15.12.2011, 21:57; Witolda Waszczykowskiego: 15.12.2011, 22:23) z sal sejmowych przy ulicy Wiejskiej.

W socjologicznej analizie emocji ważne jest kontekstualne rozumienie znaczeń. Krzysztof Konecki, powołując się na socjologa emocji Thomasa Scheffa, stwierdza, iż jednostka zawsze działa i występuje w kontekście społeczności. Uwzględnienie kontekstu społecznego jest niezwykle ważne w wyjaśnianiu działań jednostki (Konecki 2014: 32).

Omawiane wystąpienia są konsekwencją złożenia przez partię Prawo i Sprawiedliwość wniosku o wotum nieufności wobec szefa MSZ Radosława Sikorskiego po jego wypowiedzi na forum Niemieckiego Towarzystwa Polityki Zagranicznej. Minister Sikorski zaproponował tam m.in. zmniejszenie i jednoczesne wzmocnienie Komisji Europejskiej, stworzenie ogólnoeuropejskiej listy kandydatów do Parlamentu Europejskiego, połączenie stanowisk szefa KE i prezydenta UE.

Przedstawiciel wnioskodawcy - Witold Waszczykowski (były wiceszef MSZ) - w uzasadnieniu wniosku o wotum nieufności oświadczył, że

[...] propozycje przedstawione w ostatnich wypowiedziach przez ministra spraw zagranicznych prowadzą do marginalizacji i wasalizacji Polski. (http://www.tvpparlament.pl/aktualnosci/co-dalej-z-szefem-msz-dzis-glosowanie/5912998 [dostęp 30.05.2014])

Debata na ten temat zakończyła się 15 grudnia 2011 r. po godzinie 23.00. Na zarzuty kierowane pod adresem ministra Sikorskiego odpowiadał premier, według którego wniosek o wotum nieufności dotyczył polityki zagranicznej całego polskiego rządu: 
Posłowie PiS oceniali w czasie czwartkowej debaty, że Sikorski «nie powinien być dłużej twórcą i wykonawcą naszej polityki zagranicznej, ani przedstawicielem Polski wobec świata». Ich zdaniem, koncepcje polityczne Sikorskiego zbankrutowały, a on sam wejdzie do historii jako dyplomata licznych niepowodzeń, którego dyplomacja doprowadziła do wasalizacji Polski w stosunkach z sąsiadami (http://wiadomosci.dziennik.pl/polityka/artykuly/371358,radoslaw-sikorski-zostaje-na-stanowisku-ministra-spraw-zagranicznych. html [dostęp 21.11.2014]).

Szefa MSZ bronił w Sejmie premier Donald Tusk. Jak powiedział, Sikorski od pięciu lat realizuje w sposób konsekwentny politykę rządu. Tusk podkreślit, że wniosek PiS traktuje jako wniosek o wotum nieufności wobec polityki zagranicznej całego polskiego rządu (http:// wiadomosci.dziennik.pl/polityka/artykuly/371358,radoslaw-sikorski-zostaje-na-stanowisku-ministra-spraw-zagranicznych.html [dostęp 21.11.2014]).

Rzecznik PiS Adam Hofman poinformował w środę, że PiS złoży własny wniosek o wotum nieufności dla Sikorskiego. Jeszcze we wtorek prezes PiS Jarosław Kaczyński powiedział, że jego formacja poprze wniosek Solidarnej Polski. Jednak - jak zaznaczył Hofman - PiS zależało na tym, by wnioskodawcą był członek klubu PiS, «osoba dobrze przygotowana w dziedzinie stosunków międzynarodowych». Według niego, wnioskodawcą będzie b. wiceminister spraw zagranicznych Witold Waszczykowski (http://www.polskatimes.pl/ artykul/477975,pis-nie-chce-poprzec-wniosku-sp-o-wotum-nieufnoscidla-sikorskiego-zglasza-swoj-identyczny,id,t.html?cookie=1 [dostęp 21.11.2014]).

We wtorek na konferencji prasowej Kaczyński odczytał kilka artykułów konstytucji RP mówiących m.in. o suwerenności Polski. Jak dodat, dlatego cytuje konstytucję, bo została ona «w drastyczny sposób złamana» przez Sikorskiego w jego poniedziałkowym wystąpieniu w Berlinie. «To jest sprawa zasługująca na Trybunał Stanu» - oświadczył [...]. Sikorski nie miał podstaw konstytucyjnych, ustawowych, ani żadnych innych do formułowania tez, jakie wygłosił w poniedziałek w Berlinie - ocenił prezes PiS Jarosław Kaczyński. Według niego szef MSZ nie miał też politycznych podstaw, aby oferować Niemcom przywództwo w UE (http://www.polskatimes.pl/artykul/477415,sikorski-chce-iv-rzeszy-niech-sie-spakuje-i-wroci-do-waszyngtonu,id,t.html [dostęp 21.11.2014]). 
Wniosek autorstwa klubu PiS ma związek z wypowiedzią Sikorskiego w Berlinie. Szef MSZ podczas wystąpienia na forum Niemieckiego Towarzystwa Polityki Zagranicznej zaproponował m.in. zmniejszenie i jednoczesne wzmocnienie Komisji Europejskiej, ogólnoeuropejską listę kandydatów do Parlamentu Europejskiego, połączenie stanowisk szefa KE i prezydenta UE. Sikorski tłumaczył, że bliższa współpraca w ramach UE ma być odpowiedzią na kryzys (http:// www.wprost.pl/ar/281864/Sejm-wplynal-wniosek-o-wotum-nieufnosci-dla-Sikorskiego/ [dostęp 21.11.2014]).

Inną kwestią dotyczącą kontekstu przemówień sejmowych jest ich rzeczywista intencja. Ten aspekt wiąże się z całą naszą analizą, w toku której odkrywał się przed badaczami obraz prawdziwego sensu goffmanowskiego spektaklu, którego sceną stała się sala sejmowa, a aktorami ludzie, którzy na niej zasiadają, oraz widzowie telewizyjni, bowiem posiedzenia sejmowe są transmitowane przez polską telewizję publiczną.

\section{Analiza}

Analizowane przemówienia pochodzą z kanału „sejmometr" dostępnego na serwisie internetowym YouTube. Są to więc dane zastane, które na potrzeby niniejszego artykułu musiałem odpowiednio sformatować. Oczywiście najlepszą sytuacją byłoby pokazanie analizowanego materiału w jego rzeczywistej formie (zob. film na kanale YouTube), co w przypadku tekstu pisanego jest niestety niemożliwe. Wykonano zatem transkrypcję treści przemówień i zakodowano dane audio razem $z$ danymi wizualnymi. Te drugie reprezentowane są w artykule jako zrzuty ekranowe, które stanowią wizualizację przedstawianego materiału i opisywanych interakcji. Na funkcję fotografii w badaniach socjologicznych zwraca uwagę Krzysztof Konecki, według którego fotografie poszerzają i kontekstualizują niewizualne dane empiryczne, są także niejako „portretem” lub „obrazem” głównych pojęć, których 
badacz używa lub typów idealnych. Fotografie mają niejako potwierdzić słuszność wniosków badacza i zasadność użycia określonych pojęć (Konecki 2005: 49). Tutaj są one pochodną nagrań filmowych i od nich się wywodzą, oddając częściowo dynamikę naturalnych interakcji.

\subsection{Donald Tusk, przemówienie $z$ dnia 15 grudnia $2011 r^{2}$}

Najpierw - jako obrońca ministra Sikorskiego - głos zabrał premier Donald Tusk (21:57). Zarówno Tusk, jak i Waszczykowski rozpoczęli swoje przemówienia od formalnego zwrotu „Pani Marszałek! Wysoka Izbo!' Ten zwrot, wygląd, ubiór (garnitur), wyjście na mównicę czy gesty, którymi operują, stanowią istotny element goffmanowskiej fasady, czyli tę część występu jednostki, która funkcjonuje niezmiennie przez cały czas jego trwania, dostarczając obserwatorom definicji sytuacji. Fasadą są więc standardowe środki wyrazu, które jednostka stosuje celowo lub mimowolnie (Goffman 2008: 52). Fasada związana jest z elementami wyposażenia ekspresyjnego oraz sposobem prowadzenia interakcji, a jej stworzenie niesie informację, iż dany aktor jest elementem danego występu. Według E. Goffmana jeśli jednostka nie zaprezentuje się zgromadzeniu w sposób stosowny do sytuacji, może to zostać odczytane jako lekceważenie scenerii i uczestników (Goffman 2008: 30). Zarówno D. Tusk, jak i W. Waszczykowski są aktorami „wystawiającymi” przed sobą nawzajem przedstawienie. Jonathan H. Turner, powołując się na podejście dramaturgiczne E. Goffmana, stwierdza, iż przedstawienie takie często jest „cyniczne i fałszywe” (Turner 2004: 458), a aktorzy manipulują przy tym scenopisem, sceną, dekoracjami i rolami dla swych własnych celów (ibidem). Sam Goffman w swojej książce pt. Człowiek $w$ teatrze życia codziennego konsta-

2 Poniższa analiza oparta jest na filmie dostępnym na: https://www. youtube.com/watch?v=mYIv5HFh6rY [dostęp 19.11.2014]. 
tuje: „A teraz przyjmijmy punkt widzenia jednostki, która znalazła się w obecności innych. Może ona chcieć, by inni mieli o niej wysokie mniemanie albo żeby myśleli, że ma ona o nich wysokie mniemanie, albo by zorientowali się, co rzeczywiście wobec nich czuje, albo żeby mieli nieokreślone wrażenia, może chcieć stworzenia harmonijnej atmosfery po to, by przedłużyć interakcję, albo też chce swych partnerów oszukać, pozbyć się ich, zmylić, skłócić czy obrazić. Bez względu na konkretny cel, jakim kieruje się jednostka, i bez względu na przyczynę, dla której wybrała taki właśnie cel, w jej interesie będzie leżeć kontrola nad postępowaniem innych, a szczególnie nad reakcjami na jej działania” (Goffman 2008: 33). Według Goffmana taka kontrola osiągana jest poprzez wpływanie na formułowaną przez innych definicję sytuacji. Jednostka może tego dokonać, wyrażając siebie w taki sposób, aby odbierane przez innych wrażenie doprowadzało ich do dobrowolnego działania zgodnego z jej własnymi planami (ibidem: 34).

Donald Tusk tłumaczy powód swojego wystąpienia, jakim jest złożony przez PiS wniosek o odwołanie szefa MSZ Radosława Sikorskiego. Jak wspomniałem we wstępie, ważny jest kontekst - wniosek o wotum nieufności, który dla wnioskodawcy związany jest ze skandalem wokół przemówienia ministra Sikorskiego na forum Niemieckiego Towarzystwa Polityki Zagranicznej. Skandal według definicji zamieszczonej w Słowniku języka polskiego to: „wydarzenie, które wywołuje zgorszenie i oburzenie; też: atmosfera wokół takiego wydarzenia" (http://sjp.pwn.pl/szukaj/skandal. html [dostęp: 21.11.2014]). Na rolę emocji w sporach związanych ze skandalami politycznymi wskazuje Kamila Miłkowska-Samul (2013: 168): „emocje są immamentnym elementem skandalu jako formy walki politycznej. Emocje, te deklarowane i wyrażane publicznie stanowią jedno z podstawowych narzędzi uprawiania polityki”. Premier Tusk rozpoczyna swoje przemówienie od otwierającego zwrotu formalnego, po czym przechodzi do emocjonalnie zabarwionej retoryki. Formułuje sąd, jakoby wspomniany wniosek 
nie dotyczył tylko ministra Sikorskiego, ale był wotum nieufności wobec polityki zagranicznej całego polskiego rządu:

Chciałbym podkreślić z całą stanowczością, że dzisiaj wotum nieufności wobec ministra Sikorskiego nie jest wotum nieufności wobec polityki czy działań któregoś z ministrów, tylko jest zgłoszonym przez Prawo i Sprawiedliwość wotum nieufności wobec polityki zagranicznej rządu Rzeczypospolitej, konsekwentnie realizowanej nie od dwóch miesięcy czy od miesiąca, ale od pięciu lat.

Dalej w sposób ironiczny D. Tusk przedstawia cel wystąpienia, którym jest komentarz/obrona ministra Sikorskiego realizowana poprzez ironię i ośmieszenie niektórych zarzutów kierowanych pod adresem szefa MSZ:

Debata o polskiej polityce zagranicznej de facto odbyła się w godzinach południowych i popołudniowych przy okazji informacji rządu, więc czuję się zwolniony z dłuższego wykładu na temat ministra Sikorskiego, oceny jego działań [...].

[...] wystąpienie posła wnioskodawcy pana Waszczykowskiego było próbą wyjaśnienia tej zaskakującej, wydawałoby się, gorliwości. Usłyszeliśmy w wystąpieniu posła wnioskodawcy, że były bardzo różne powody, dla których PiS postanowił zgłosić to wotum nieufności. Wśród tych oskarżeń znalazły się takie epitety, jak brak wyrazistej polityki wobec państw Sahelu [...].

(Poseł Antoni Macierewicz: To jest epitet?)

[...] Pragmatyzm - to, że minister spraw zagranicznych Polski jest pragmatykiem, było chyba najcięższym oskarżeniem (oklaski) - usłyszeliśmy, że minister Sikorski odpowiada za wynik wyborów w Rosji i za to, że Wschód nie stał się Zachodem.

Muszę powiedzieć, że zarówno ja, jako szef rządu, jak i, myślę, państwo na tej sali mamy duże oczekiwania wobec ministra Sikorskiego, biorąc pod uwagę jego talenty, inteligencję i kompetencję, ale żeby Wschód stał się Zachodem, szczerze powiedziawszy, takich oczekiwań nie mieliśmy. 


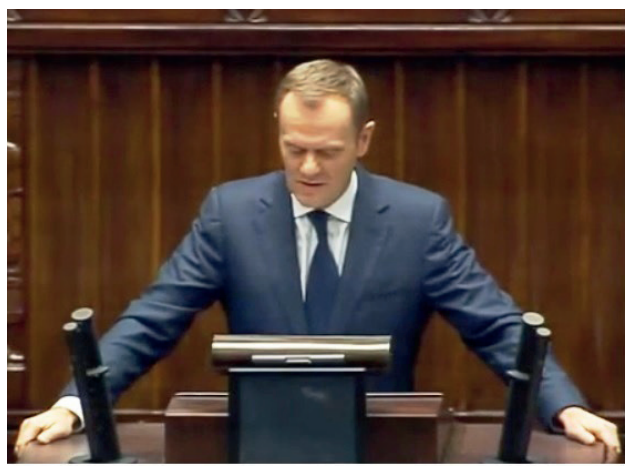

Fot. 1. Wzrok premiera właściwie cały czas skierowany jest na treść przemówienia Źródło: http://youtu.be/mYlv5HFh6rY

Premier Donald Tusk unika kontaktu wzrokowego z posłem wnioskodawcą - Witoldem Waszczykowskim. Prawdopodobnie jest zakłopotany swoją bezpośrednią krytyką adwersarza debaty. Skupia się na treści przemówienia. Jednak kiedy w celu ośmieszenia złożonego przez PiS wniosku o wotum nieufności wymienia powody, które zadecydowały o wspomnianym wniosku i w chwili, gdy spotyka się z reakcją sali (poruszenie i brawa), podnoszą mu się brwi, unosi głowę oraz spogląda wymownie w kierunku swoich zwolenników. Szuka wsparcia dla swej ośmieszającej riposty.

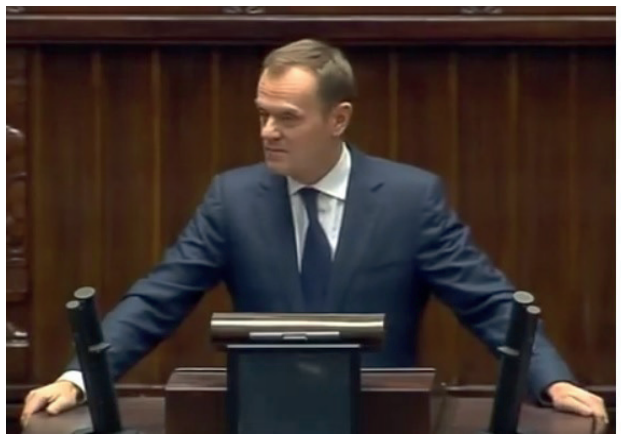

Fot. 2. Premier spogląda w stronę zwolenników, którzy czynnie uczestniczą w interakcji Źródło: http://youtu.be/mYlv5HFh6rY 
Przemawiający D. Tusk zwraca się bezpośrednio do osoby Władysława Waszczykowskiego. Za drugim razem, choć wiadomo, że premier Tusk ustosunkowuje się do przemówienia posła Waszczykowskiego, używa zwrotu „uslyszeliśmy w wystapieniu posła wnioskodawcy". Ów poseł nie zasługuje nawet na wymienienie z imienia i nazwiska, co może wskazywać na zabieg symbolicznego odmówienia w pewnym stopniu „indywidualnej tożsamości” osobie, której słowa są przytaczane. Sama chęć odniesienia się do wniosku PiS zdaje się jedynie pretekstem do ataku na przeciwników politycznych, partnerów swoistej gry interakcyjnej. Język przemawiającego jest silnie zabarwiony emocjonalnie:

[...] wystąpienie posła wnioskodawcy pana Waszczykowskiego było próbą wyjaśnienia tej zaskakującej, wydawałoby się, gorliwości..., ustyszeliśmy, że minister Sikorski odpowiada za wynik wyborów w Rosji i za to, że Wschód nie stał się Zachodem..., zarówno ja jako szef rządu, jak i, myślę, państwo na tej sali mamy duże oczekiwania wobec ministra Sikorskiego, biorąc pod uwagę jego talenty, inteligencję i kompetencje, ale żeby Wschód stał się Zachodem, szczerze powiedziawszy, takich oczekiwań nie mieliśmy. Można by w tak lekki sposób kwitować całe wystąpienie ministra Waszczykowskiego.

Dodatkowo, kiedy Donald Tusk mówi „ustyszeliśmy, że minister Sikorski odpowiada za wynik wyborów w Rosji i za to, że Wschód nie stał się Zachodem...", zdaje się użyć - świadomie czy też nie - jednego $\mathrm{z}$ opisanych przez niemieckiego filozofa Arthura Schopenhauera sposobów prowadzenia sporu: „Z wypowiedzi przeciwnika wydobywa się sztucznie, przez fałszywe wnioskowanie i przeinaczanie pojęć, twierdzenia zupełnie w niej nieobecne, ani też niezamierzone, które są natomiast absurdalne i niebezpieczne; stworzywszy wrażenie, iż płyną one właśnie $\mathrm{z}$ wypowiedzi przeciwnika i są sprzeczne między sobą oraz z ogólnie przyjętymi prawdami, osiągamy pośrednie 
zakwestionowanie twierdzenia apagoge (poprzez niemożność twierdzenia przeciwnego). Jest to zatem znów zastosowanie metody fallacia non cause ul causa (potraktowanie czegoś, co nie jest przyczyną jako przyczyny)" (Schopenhauer 1973: 66-68). Silnie zauważalny jest też prymat emocji nad merytoryczną wypowiedzią. Według Piotra Michałowskiego, im coś jest bardziej skandalizujące, tym mniej zawiera oczywistości (Michałowski 2003: 75). Użycie zwrotów wartościujących i emocjonalnie zabarwionych służyć ma wywołaniu zakłopotania oraz wskazaniu kto, według Donalda Tuska, jest winny zaistniałej sytuacji. W wypowiedzi premiera, zarzuty wobec polityki zagranicznej Sikorskiego formułowane przez Witolda Waszczykowskiego przedstawiciela wnioskodawców, zostały poddane interpretacji i użyte w celu podkreślenia irracjonalności ich samych, jak i całego wniosku o odwołanie szefa MSZ.

W kolejnej części przemówienia, Donald Tusk pokazuje prawdziwy powód zgłoszenia wotum nieufności - wskazuje go dwa razy, używa powtórzenia - jakim jest „treść i miejsce tego wystąpienia”. Premier oskarża swoich przeciwników o formułowanie bezpodstawnych zarzutów, epitetów i insynuacji. Posługuje się sarkazmem, chcąc pozbawić twarzy swoich przeciwników, a z drugiej strony odzyskać twarz własną i „swojego ministra”:

Można by w tak lekki sposób kwitować całe wystąpienie ministra Waszczykowskiego, ale prawdziwym powodem, jeśli dobrze zrozumiałem nie tylko jego wystąpienie, ale także komentarze polityków prawicy po wystąpieniu berlińskim ministra Sikorskiego, jest treść i miejsce tego wystąpienia. Wszystkie inne zarzuty, epitety, momentami insynuacje wydają się tylko dekoracją dla tego najcięższego oskarżenia, jakim jest treść i miejsce wystąpienia ministra Sikorskiego sprzed kilkunastu dni.

Na zakończenie przemowy D. Tusk przytacza słowa Lecha Kaczyńskiego, wyraźnie się od nich dystansując: 
[...] koniecznie cudzysłów, żeby nikt nawet przez moment nie przypisywał tych słów mnie lub ministrowi Sikorskiemu.

Przemawiający jakby przypomniał sobie, że musi potwierdzić, iż wypowiadane słowa nie są jego autorstwa. Trudno nie oprzeć się wrażeniu, że była to gra aktorska w wykonaniu Donalda Tuska, który ironizując, chce uwypuklić bezsens i irracjonalność wypowiedzi prezydenta, by ironizować w stosunku do obecnej formacji PiS. Tusk podkreśla przy tym, iż PiS zmienia stanowisko, ponieważ kiedy sam był u władzy, to dużo przychylniej odnosił się do instytucji Unii Europejskiej:

Po pierwsze, data: 8 marca 2006 r., po drugie, miejsce: Berlin, Uniwersytet Humboldta, po trzecie, słowa wystąpienia. «Mówię, jako jeden - koniecznie cudzysłów, żeby nikt nawet przez moment nie przypisywał tych słów mnie lub ministrowi Sikorskiemu - z obywateli Polski, a więc dzisiaj obywateli Unii Europejskiej. Wiem, że nasze stanowisko jest sprawdzianem solidarności, ale jeżeli Europa chce ten sprawdzian zdać, jeżeli chce stworzyć nową jakość - nie na dwa, trzy pokolenia, co się udało dotychczas, tylko na wiele pokoleń nową jakość, która być może kiedyś w historii będzie rzeczywiście też jakością o charakterze federacji, federacji przecież wtedy niezmiernie potężnej w skali świata, to musi ten egzamin również zdać. I do tego bym zachęcat, reprezentując kraj, który oczywiście w tej chwili korzysta dzięki członkostwu w Unii Europejskiej, ale który jeżeli to, o czym mówię, spełnitoby się w ciągu ośmiu czy dziesięciu lat - będzie korzystał mniej.

Zdaję sobie z tego sprawę i z góry się na to zgadzam. Dziękuję bardzo». Kropka, koniec cytatu. Autor: Lech Kaczyński.

Dziękuję bardzo. 


\subsection{Witold Waszczykowski, przemówienie z dnia 15 grudnia 2011r. ${ }^{3}$}

Jak wspomniałem przy okazji przemówienia Donalda Tuska, Witold Waszczykowski również rozpoczyna swoją mowę od formalnego zwrotu otwierającego „Pani Marszałek! Wysoka Izbo!" Po tym stwierdzeniu przemawiający ironizuje, odchodzi od tematu sporu, odnosząc się bezpośrednio do osoby Donalda Tuska:

Jestem wzruszony tym, że moje wystąpienie zostało zauważone przez pana premiera Donalda Tuska...

(Prezes Rady Ministrów Donald Tusk: Za dużo powiedziane).

...ale rozumiem, ciężki mecz, głowa boli, nie wszystko pan premier zrozumiał, więc może się odniosę do niektórych rzeczy.

Według Schopenhauera osoby uciekają się do takich kroków, kiedy spostrzegą, że przeciwnik jest silniejszy, a nasze racje mogą być zagrożone. Ten chwyt stanowi ostatni ze sposobów prowadzenia sporów opisany przez Schopenhauera, według którego polega on na tym, że: „(mając i tak już sprawę przegraną) porzuca się przedmiot sporu i zamiast tego atakuje osobę przeciwnika w jakikolwiek bądź sposób; można by to nazwać argumentum ad personam, w odróżnieniu od argumentum ad hominem; przy tym ostatnim odchodzi się od przedmiotu sporu pojmowanego czysto obiektywnie i atakuje się to, co przeciwnik sam o tym powiedział lub przyznał. Natomiast przy ataku osobistym odchodzi się całkowicie od przedmiotu i natarcie kieruje się na osobę przeciwnika; postępuje się więc w sposób krzywdzący, złośliwy, obraźliwy,

3 Poniższa analiza oparta jest na filmie dostępnym na: https://www. youtube.com/watch?v=ylwUtDlaEWU [dostęp 19.11.2014]. 
grubiański” (Schopenhauer 1973: 86-87). Artur Schopenhauer konstatuje przy tym, iż z reguły tej korzysta się chętnie, bo każdy jest zdolny do jej zastosowania, więc używa jej się nader często (ibidem: 87).

Analizując transkrypcję wypowiedzi W. Waszczykowskiego, nie znając kontekstu i specyfiki wystąpień sejmowych, można odnieść wrażenie, że rzeczywiście czuje się on poruszony odniesieniem Donalda Tuska do jego osoby. Jednak, gdy patrzymy na nagranie i słyszymy głos, którym wypowiada te słowa, nie mamy żadnej wątpliwości, iż jest to zwrot retoryczny (ironia) mający na celu ośmieszenie przeciwnika.

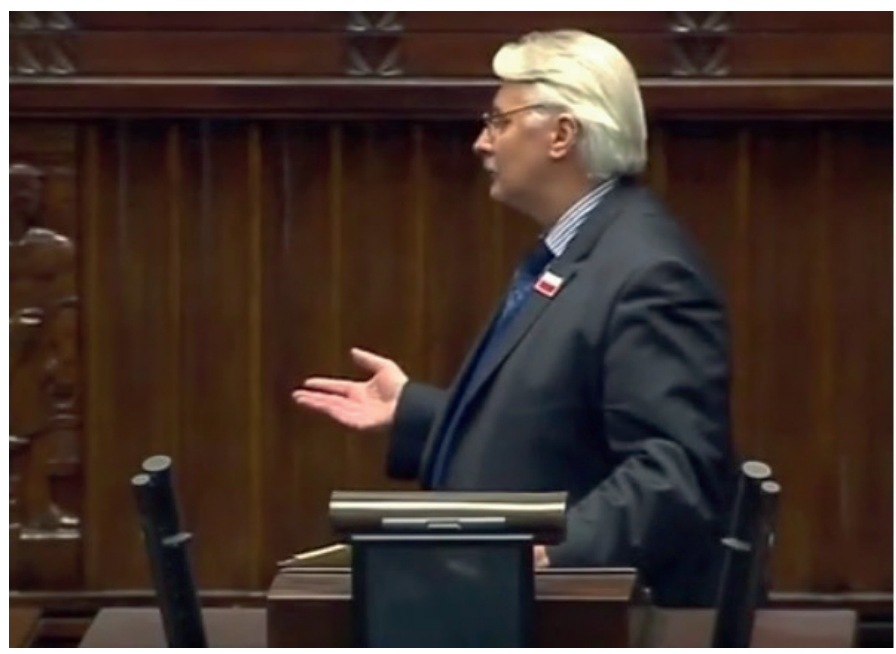

Fot. 3. Witold Waszczykowski odwraca się w stronę Donalda Tuska i gestykulując zwraca się bezpośrednio do niego

Źródło: https://www.youtube.com/watch?v=ylwUtDlaEWU

Zresztą Donald Tusk podejmuje tę emocjonalną grę „wstydupokorzenie” i z sali sejmowej odpowiada przemawiającemu z mównicy Waszczykowskiemu: „Za dużo powiedziane”. 
W następnej części przemówienia poseł Waszczykowski przypisuje szyderstwo Donaldowi Tuskowi „Lepiej szydzić, niż odnieść się do rzeczy". Warto zaznaczyć, że o ile przemawiający rozpoznaje złe intencje i ironię u przeciwnika, to jednocześnie nie chce zauważyć, iż jego przemówienie również oparte jest na próbie ośmieszania i ironii.

Poseł Waszczykowski w swej mowie odnosi się do wystąpienia swojego poprzednika. Po kolei wymienia błędy w rozumowaniu Donalda Tuska. Korzysta przy tym z notatek, chce pokazać, iż jest merytorycznie przygotowany do debaty. Odniesienie do wystąpienia D. Tuska jest jednak tylko przyczynkiem do emocjonalnie zabarwionej, ironicznej wypowiedzi. Wszak język i styl, którym operuje Waszczykowski, wcale nie wskazuje na rzeczową dyskusję. Tak samo jak jego kontrpartner stosuje on głównie retorykę opartą na emocjach, chcąc wywołać poczucie zakłopotania, czy szerzej rzecz ujmując - wstydu u przeciwnika. Taka strategia działania ma doprowadzić do „utraty twarzy” partnera interakcji. Pojęcie „twarzy” według Ervinga Goffmana „odnosi się do pozytywnej wartości społecznej przypisywanej osobie w danej sytuacji spotkania, gdy inni przyjmą, że trzyma się ona określonej roli [...]. O osobie można powiedzieć, że «ma» albo «zachowuje» twarz wówczas, gdy rola, której konsekwentnie się trzyma, tworzy spójny obraz tej osoby w danej sytuacji [...]" (Goffman 2006: $5,7)$, natomiast pojęcie „utraty twarzy” „znaczy tyle, co pomylić role, wypaść z roli czy zawstydzić się" (ibidem: 9). Innym mechanizmem stosowanym przez Waszczykowskiego w celu doprowadzenia do „utraty twarzy” przez Donalda Tuska jest pouczanie go z mównicy oraz definiowanie pojęcia "pragmatyczna polityka”, którego według przemawiającego premier Tusk nie rozumie:

Po pierwsze, nie zrozumiał pan, co to znaczy pragmatyczna polityka. Pragmatyczna polityka to jest polityka bez zasad, nieoparta na normach, standardach, wartościach, to jest polityka transakcyjna. 
(oklaski)

Tak podsumowat to kiedyś profesor Nałęcz: warto było dać każdą cenę za przyjazd Putina do Katynia. No to zapłaciliśmy.

(głos z Sali - Donald Tusk: Bo powiemy coś więcej!)

Proszę. Po drugie, wybory w Rosji. Znowu pan coś usłyszał, ale nie zrozumiał, i mamy oskarżenia. Ja pytałem, czy ten eksperyment, umowa, jaką podpisat pan minister w Rosji, wart jest tego, aby to robić w tej chwili, po tych wyborach w Rosji, które poszły tak, jak poszty.

Po trzecie, odniosłem się do agendy unijnej, do której pan minister od lat się nie odnosi. Pan ustyszał egzotyczne słowo Sahel. No, ale ja pytałem, co w kryzysowych, ważnych sprawach ten pan ma do powiedzenia. Być może niedługo będzie interwencja w Iranie, wali się Bliski Wschód. Nie ma żadnej odpowiedzi.

Trzeba zaznaczyć, iż korzystając z materiałów zastanych (filmów z portalu YouTube), ja jako badacz jestem odbiorcą pewnej subiektywnej konstrukcji, przekazywanej szerszej, medialnej publiczności przez operatora kamery, który decyduje, na czym lub na kim w danej chwili skupia swoją uwagę. Traktując dane wizualne jako materiały pomocnicze, należy pamiętać, że w takim podejściu dane wizualne użyte są do rekonstrukcji wizualnych procesów, działań i interakcji. „Analiza obejmuje tutaj także oczekiwania odbiorców i postrzegane wzory kultur i subkultur wizualnych, które stanowią społeczny i kulturowy kontekst produkcji i prezentacji obrazów" (Konecki 2012: 21). Kiedy poseł Waszczykowski definiuje - zdawałoby się, specjalnie dla Donalda Tuska - pojęcie pragmatycznej polityki, operator przenosi swoją uwagę - a tym samym wzrok kamery - w stronę ław zajmowanych przez najważniejszych polityków Platformy Obywatelskiej. 

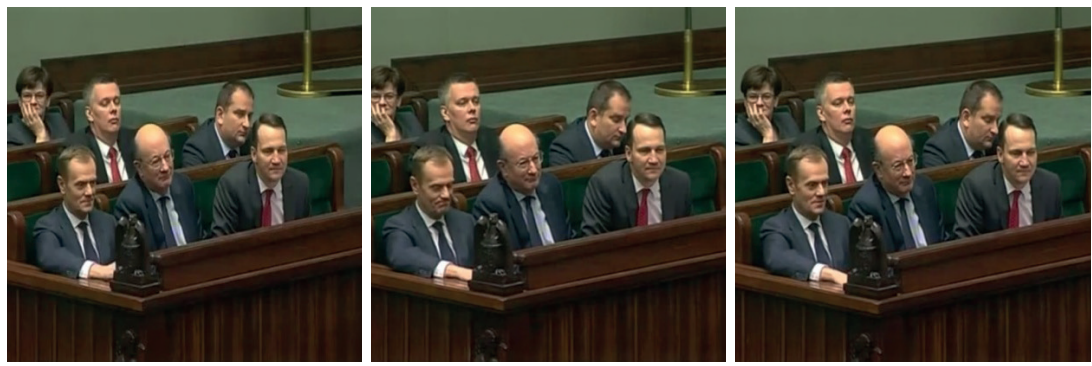

Fot. 4, 5, 6. Reakcja ławy rządowej na słowa posła Waszczykowskiego

Źródło: https://www.youtube.com/watch?v=ylwUtDlaEWU

O ile siedzący obok premiera Jacek Rostowski i Radosław Sikorski nie reagują na słowa Witolda Waszczykowskiego (niemalże zamarli w obranych pozach: J. Rostowski lekko pochylony w prawą stronę, R. Sikorski pochylony do przodu, usta zaciśnięte, głowa nieruchoma), to Donald Tusk podejmuje interakcję i gdy poseł Waszczykowski poucza premiera z mównicy, ten potakuje ironicznie głową, nerwowo zaciskając usta. W dalszej części wystąpienia Waszczykowski wspomina wypowiedź Tomasza Nałęcza (podkreśla, że tak niestosowne słowa padły z ust człowieka legitymującego się tytułem naukowym profesora), które odnosi w prosty sposób do osoby Władimira Putina i Katynia (miejsca szczególnego dla polskiej historii i przez to silnie zabarwionego emocjonalnie): „Tak podsumował to kiedyś profesor Nałęcz: warto było dać każda cenę za przyjazd Putina do Katynia. No to zapłaciliśmy", Donald Tusk podejmuje walkę o utrzymanie twarzy i nerwowo kręcąc głową, odpowiada personalnie przemawiającemu z mównicy posłowi: „Bo powiemy coś więcej!"

Poseł Waszczykowski po krótkiej pauzie, jakby z przykrością w głosie, przechodzi do finalnego - czwartego punktu swojego wystąpienia. Chodzi tu o przytoczenie przez Donalda Tuska słów Lecha Kaczyńskiego. Waszczykowski poddaje ten 
zabieg silnej ocenie wartościującej. Uważa, iż jest to chwyt wysoce niestosowny, jednocześnie wyliczając i podkreślając cechy L. Kaczyńskiego, które mają wskazywać na jego autorytet i profesjonalizm. Waszczykowski podejmuje walkę, której stawką jest dobre imię nieżyjącego prezydenta Rzeczpospolitej Polskiej. Na koniec symbolicznie odsyła Donalda Tuska do źródeł, na których powinien opierać swoje sądy:

I wreszcie czwarty punkt, haniebny. Odniósł się pan do wystąpienia profesora Lecha Kaczyńskiego, prawnika, na uniwersytecie, czyli we właściwym miejscu, gdzie dyskutowat, rozważat problem federalizmu. Proszę zobaczyć, do czego tam on się zobowiązat. Niech pan sprawdzi, czy on się do czegoś zobowiązat, i nam pokaże. Dziękuję bardzo (oklaski).

Analizując zaistniały spór między Donaldem Tuskiem a Witoldem Waszczykowskim, być może powinienem wyjść od pytania o motywy, których zrozumienie pozwala wyjaśnić, dlaczego partnerzy interakcji postępują w określony sposób. Według E. Hałas „motywy dotyczą tego, co ludzie mówią o swoim postępowaniu, a nie czynników, które kształtują jego fazę impulsywną. Motyw jest więc koncepcją ściśle związaną z koncepcją «Mnie». Wskazuje on na ten aspekt działań, jakim jest szukanie przez osobę wyjaśnienia swego własnego postępowania i postępowania innych" (Hałas 2006: 191-192). Takie rozumowanie odnosi się do symboliczno-interakcyjnych koncepcji motywów, przedstawicielem których jest m.in. C. Wright Mills, „ujmujący motywy jako jednostki interpretacji działań - społeczne konstrukty" (Hałas 2006: 192). Pytając o motywy zaistniałego sporu, pytam - w duchu interakcjonizmu symbolicznego - o to ,jak działanie przebiega?” Aby odpowiedzieć na zadane pytanie, należy opisać sytuację i jej typowy słownik motywów, tzn. taki, który zazwyczaj towarzyszy danemu typowi sytuacji i funkcjonuje jako zarazem wskazówka i usprawiedliwienie normatywnych 
działań w niej zachodzących. Motywy są typowymi i względnie niekwestionowalnymi składnikami zwykłych sytuacji ${ }^{4}$. Sprowadza się je do obserwowalnej rozmowy o motywach (Hałas 2006: 193, [za:] Hewitt 1979: 141; 2000: 154), która jest centralną cechą doświadczenia codziennego. Motywy są przypisywane lub wyznawane jako odpowiedzi na pytania przerywające działania lub ich programy (Hałas 2006: 194, [za:] Blum, McHugh 1971: 98). Natomiast warunkiem rozmowy o motywach jest pewien przyjęty zasób wiedzy - nieproblematyczne tło, w odniesieniu do którego pojawia się problematyczność danego działania (jego nietypowy charakter, bezcelowość czy niewłaściwe użycie w określonej sytuacji) oraz wspomniany wcześniej słownik motywów, czyli zasób społecznie uznanych odpowiedzi na takie pytanie (Hałas 2006: 194).

Donald Tusk, jak i Witold Waszczykowski korzystają z takiego sytuacyjnego słownika motywów, skupionego wobec określonego społecznego działania, konwersacji, konfliktu (Hałas 2006: 193, [za:] Mills 1940: 905). Donald Tusk już na samym początku swojego przemówienia tłumaczy:

Chciałbym podkreślić z całą stanowczością, że dzisiaj wotum nieufności wobec ministra Sikorskiego nie jest wotum nieufności wobec polityki czy działań któregoś z ministrów, tylko jest zgłoszonym przez Prawo i Sprawiedliwość wotum nieufności wobec polityki zagranicznej rządu Rzeczypospolitej [...],

pyta retorycznie o motywy działania swoich oponentów:

jest rzeczą zastanawiającą, dlaczego ta konsekwentnie realizowana polityka wzbudziła nagle emocje wśród polityków Prawa i Sprawiedliwości, takie emocje, że zgłoszono w rekordowym w historii Polski tempie wniosek o wotum nieufności,

4 Spór na linii rząd-opozycja jest właśnie takim typowym działaniem zachodzącym w świecie polityki. 
by następnie w ironizujący sposób odpowiedzieć publiczności i sobie samemu na zadane pytanie:

[...] ale wystąpienie posła wnioskodawcy pana Waszczykowskiego było próbą wyjaśnienia tej zaskakującej, wydawałoby się, gorliwości. Usłyszeliśmy w wystąpieniu posła wnioskodawcy, że były bardzo różne powody, dla których PiS postanowił zgłosić to wotum nieufności [...]. Wśród tych oskarżeń znalazły się takie epitety, jak brak wyrazistej polityki wobec państw Sahelu [...] pragmatyzm [...] usłyszeliśmy, że minister Sikorski odpowiada za wynik wyborów w Rosji i za to, że Wschód nie stał się Zachodem [...]. Można by w tak lekki sposób kwitować całe wystąpienie ministra Waszczykowskiego, ale prawdziwym powodem, jeśli dobrze zrozumiałem nie tylko jego wystąpienie, ale także komentarze polityków prawicy po wystąpieniu berlińskim ministra Sikorskiego, jest treść i miejsce tego wystąpienia.

W przypadku Witolda Waszczykowskiego wskazówką do zrozumienia podjętego działania może być uzasadnienie wniosku o wotum nieufności, w którym poseł Waszczykowski stwierdził, że

propozycje przedstawione w ostatnich wypowiedziach przez ministra spraw zagranicznych prowadzą do marginalizacji i wasalizacji Polski.

Wniosek o wotum nieufności to ogólny motyw sytuacyjnego działania, wokół którego skonstruowana jest interakcja TuskWaszczykowski. Bezpośrednią przyczyną przemówienia jest działanie o charakterze rewanżu, w którym - o czym wspominałem na początku analizy wystąpienia - poseł Waszczykowski ironizuje, odnosząc się personalnie do osoby Donalda Tuska:

Dziękuję. Pani Marszałek! Wysoka Izbo! Króciutko. Jestem wzruszony tym, że moje wystąpienie zostało zauważone przez pana premiera Donalda Tuska, [...] ale rozumiem, ciężki mecz, głowa boli, nie wszystko pan premier zrozumiat, więc może się odniosę do niektórych rzeczy, 
by następnie wymienić błędy w rozumowaniu i działaniach podjętych przez politycznego przeciwnika:

Po pierwsze, nie zrozumiał pan, co to znaczy pragmatyczna polityka. [...]. Po drugie, wybory w Rosji. Znowu pan coś ustyszat, ale nie zrozumiał, i mamy oskarżenia. [...] Po trzecie, odniosłem się do agendy unijnej, do której pan minister od lat się nie odnosi. [...] I wreszcie czwarty punkt, haniebny. Odnióst się pan do wystąpienia profesora Lecha Kaczyńskiego, prawnika, na uniwersytecie [...]. Proszę zobaczyć, do czego tam on się zobowiązat. Niech pan sprawdzi, czy on się do czegoś zobowiązat, i nam pokaże.

\section{Gesty}

Zachowanie i gesty wskazują na emocjonalny charakter interakcji. Donald Tusk na mównicy wydaje się być pewny siebie. Jednak jego zachowanie może zdradzać, że ta pewność jest raczej wynikiem pracy nad twarzą i chęcią jej zachowania. Kategoria „utraty twarzy” zdaniem K. Koneckiego jest kluczowym pojęciem koncepcji rytuału ośmieszania. „Najbardziej interesujące nas pojęcie «utraty twarzy» Goffman definiuje następująco: „Sformułowanie «stracić twarz» (to lose face) oznacza ukazywanie niewłaściwej twarzy, bycie bez twarzy lub bycie zawstydzonym przez kogoś" (Konecki 2007: 60, [za:] Goffman 1967: 9). „Zawstydzenie jest tutaj związane z utratą kontroli nad emocjami i niemożnością ukrycia faktu, iż utrata twarzy wywołuje w jednostce negatywne emocje. Widzimy tutaj, że określonym formom bycia w interakcji towarzyszą określone emocje, przy utracie twarzy są to emocje negatywne" (Konecki 2007: 60). Wzrok premiera skierowany jest na jakiś oddalony obiekt, a głowa wędruje od lewej do prawej strony - byle tylko nie spotkać się ze wzrokiem adwersarzy - czasami zastygając w celu spojrzenia $\mathrm{w}$ przygotowane przemówienie. Kiedy Donald Tusk spogląda w notatki, jego ręce automatycznie podnoszą je z mów- 

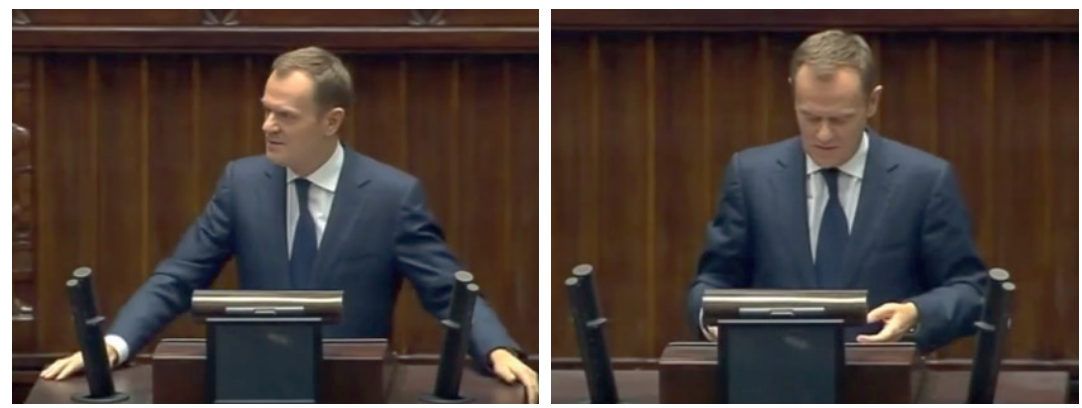

Fot. 7, 8. Donald Tusk wodzi wzrokiem po sali. Od czasu do czasu podnosi z mównicy kartki z przemówieniem Źródło: https://www.youtube.com/watch?v=mYlv5HFh6rY

nicy. Nie mam pewności, czy to bezwarunkowy odruch czy też wyuczony gest, który ma podkreślić merytoryczne i dobre przygotowanie (wszak premier nie improwizuje, nie wróży z przysłowiowych fusów, a jest dobrze przygotowany do przemówienia).

Styl przemawiania Witolda Waszczykowskiego jest zupełnie inny. Głosząc swoją mowę, stoi odwrócony bokiem w kierunku loży rządowej. Jedną ręką stara się szukać podparcia na mównicy, natomiast w drugiej trzyma notatki bądź treść przemówienia. Nie jest taki spokojny, przeskakuje z nogi na nogę i gestykuluje nerwowo ręką. Widać, że wystąpienie niesie ze sobą duży ładunek emocjonalny, co słychać również w podniesionym głosie posła Waszczykowskiego. Kiedy Donald Tusk odnosi się do słów Witolda Waszczykowskiego uzasadniających wniosek o odwołanie szefa MSZ, ten drugi nerwowo przytyka dłoń do ust i wodzi wzrokiem po sali. Jest to przejaw podjętej walki o zachowanie twarzy, co wiąże się z dbałością o fasadę atakowanego. Według Goffmana „do najbardziej czułych instrumentów osobistej fasady należy wyraz twarzy. Niezwykle istotnym sposobem okazywania obecności sytuacyjnej jest kontrola kształtu i wyglądu różnych części twarzy [...]" (Goffman 2008: 32). W innej części książki 
Zachowanie w miejscach publicznych E. Goffman dodaje: „Patrzenie sobie w oczy odgrywa zatem szczególną rolę w komunikacji społecznej, w rytualny sposób ustanawiając otwartość na komunikaty słowne oraz odpowiednio uwydatniając wzajemną doniosłość aktów komunikacji” (ibidem: 103). Z tego właśnie powodu Witold Waszczykowski, chcąc ratować swoją twarz, odwraca wzrok i wodzi spojrzeniem po sali sejmowej, byleby tylko nie zaangażować się bezpośrednio w interakcję z Donaldem Tuskiem. Jak konstatuje Goffman „chcąc uniknąć spotkania, należy nie dopuścić do wymiany spojrzeń, ponieważ kontakt wzrokowy otwiera człowieka na zaangażowanie twarzy" (ibidem: 106).
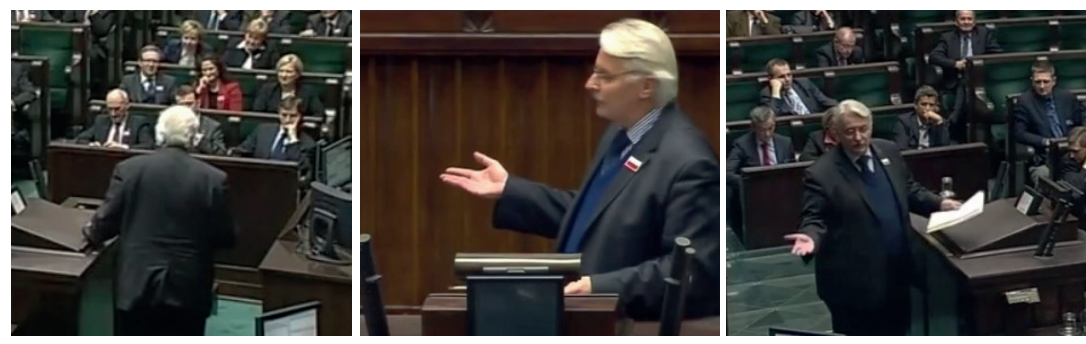

Fot. 9, 10, 11. Witold Waszczykowski odwraca się w stronę loży rządowej, gestykuluje i wskazuje ręką na przeciwników politycznych

Źródło: https://www.youtube.com/watch?v=ylwUtDlaEWU
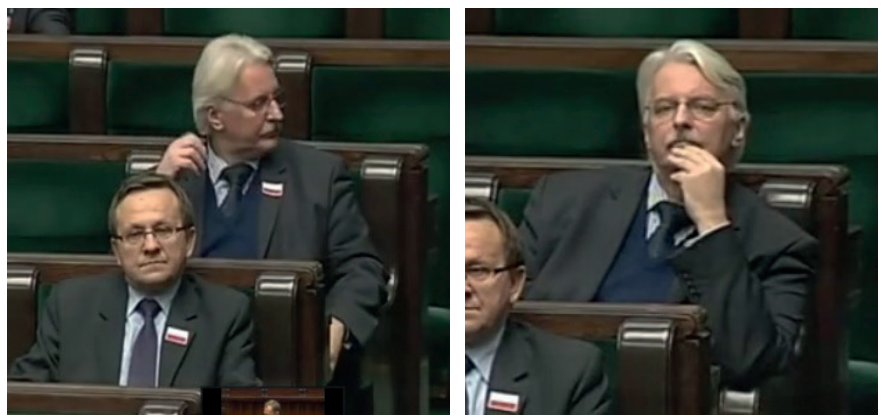

Fot. 12, 13. Nerwowa reakcja posła Waszczykowskiego na słowa premiera Tuska Źródło: https://www.youtube.com/watch?v=mYlv5HFh6rY 
Aktorzy podejmują również kontrzabiegi w celu zachowania twarzy czy też jej odzyskania. Wywołany do przysłowiowej tablicy Donald Tusk obejmuje mównicę we władanie. Szeroko rozkłada ręce i mocno trzyma się jej rogów. Pokazuje, że panuje nad sytuacją, jest silny i pewny siebie, natomiast Witold Waszczykowski wskazuje zdecydowanie swoją dłonią, kto jest winny zaistniałej sytuacji, wzmacniając w ten sposób swoją krytykę rządu.

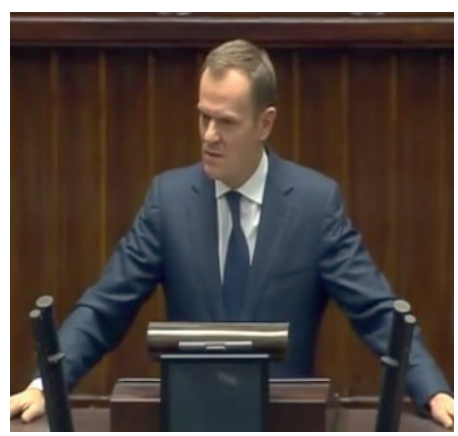

Fot. 14. Donald Tusk obejmuje mównicę we władanie Źródło: https://www.youtube.com/watch?v=mYlv5HFh6rY

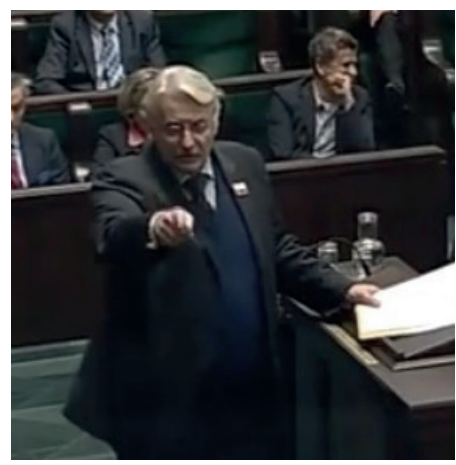

Fot. 15. Witold Waszczykowski odwraca się w stronę loży rządowej i wskazuje ręką na przeciwników politycznych Źródło: https://www.youtube.com/watch?v=ylwUtDlaEWU 
Należy zaznaczyć, iż gra, która toczy się na sali sejmowej, wykracza poza przemawiające osoby. Znajdujący się na sali aktorzy drugoplanowi reagują na retoryczne zabiegi i, w zależności od politycznej opcji, poprzez: oklaski, śmiech (dwoista rola śmiechu, raz stosowany jest jako narzędzie ośmieszenia, innym razem jako wyrażenie aprobaty - kontekst ujawnia intencje) czy uderzanie w krzesła, wyrażają swoją aprobatę lub pochwałę ośmieszania przeciwnika politycznego. Ponadto mamy tutaj publiczność telewizyjną czy sieciową, bowiem debaty sejmowe są transmitowane i również do tej publiczności przedstawione wypowiedzi są pośrednio skierowane. Według Bogusławy Dobek-Ostrowskiej (2011: 116), autorki książki Polski system medialny na rozdro$\dot{z} u$. Media $w$ polityce, polityka $w$ mediach, „aktorzy polityczni, w zależności od norm prawnych, tradycji i kultury politycznej, profesjonalizmu dziennikarskiego, starają się za pomocą dostępnych instrumentów wpływać na zawartość mediów, aby w ten sposób zarządzać własnym wizerunkiem i deprecjonować przeciwników". Obserwowane zmiany w sferze uprawiania polityki (prymat emocji nad merytoryczną debatą, wzrost roli wizerunku medialnego, brak dialogu między aktorami sceny politycznej, a zamiast tego wzajemne obwinianie i ośmieszanie) mogą świadczyć o wkroczeniu w erę postpolityki, której naturalną cechą jest to, że „emocje zajęły miejsce programów, zaś wizerunek zdystansował idee" (Mistewicz 2011: 68). Porządek postpolityczny charakteryzuje się odejściem od sporów ideologicznych, natomiast sama ideologia zdaje się być uproszczona do minimum, tak aby dobrze prezentowała się w krótkich przekazach medialnych (nie bez powodu wykorzystuje się nowe technologie). Jak zauważa Aleksandra Seklecka (Seklecka, [w:] Jeziński 2011: 89, 90) „nowe media, a w szczególności Internet stanowią doskonałe medium do kreowania wizerunku polityka i partii politycznej [...]. Działania te jednakże często mogą przybliżyć się do prób manipulowania eksponowanym wizerunkiem. [...] Manipulacja przejawia się 
poprzez eksponowanie pewnych cech czy wydarzeń korzystnych dla kreowanego podmiotu, bądź też retuszowanie umożliwiające prezentację polityka w korzystnym świetle”. Badacze świata polityki podkreślają rolę mediów, które wpływają na przekaz polityczny oraz rosnącą rolę wykwalifikowanych fachowców od marketingu politycznego. Błażej Sajduk - w iście goffmanowskim duchu - definiuje postpolitykę jako system póz, masek i zasłon, za którymi odgrywa się prawdziwe rządzenie. Kusząca wydaje się metafora prestidigitatora, który wyciąga widzom z ucha monety, uprzednio odwróciwszy ich uwagę. W takim ujęciu postpolityka to nie zagrożenie, a jedynie narzędzie jeszcze sprawniejszego rządzenia. Pozwala ono generować wirtualne konflikty i wirtualnie je rozwiązywać (wszystko przez i za pomocą mediów), dzięki czemu społeczeństwu daje się możliwość budowania namiastki tożsamości politycznej, bez tracenia czasu na wyjaśnianie, czym prawdziwa polityka jest (Sajduk 2008: http://www.omp.org.pl/ stareomp/index719e.html?module=subjects \&func=viewpage $\&$ pageid=722 [dostęp 09.12.2014]). Ewa Pietrzyk-Zieniewicz, analizując język mediów, podkreśla, że współcześnie obserwujemy te same mechanizmy manipulacyjne, które rządziły językiem nowomowy, tzn. emocjonalizację odbioru, sugerowanie wspólnoty języka i świata, symplifikowanie i antytetyczny rozkład racji (dychotomiczny podział na czarne i białe), konstruowanie tzw. odbioru bezalternatywnego. Wnioski płynące $\mathrm{z}$ mojej analizy wskazują, iż prawda nie jest wartością obiektywną, jest ona konstruowana. Ponadto jest interpretacją na potrzeby prowadzonego dyskursu politycznego. Jak twierdzi francuski filozof Michel Foucault: „Każde społeczeństwo ma swój własny reżim prawdy, swoją "ogólną politykę» prawdy: to znaczy takie typy dyskursu, które akceptuje, i sprawia, że funkcjonują one jako prawdziwe; mechanizmy i instancje, które umożliwiają odróżnienie twierdzeń prawdziwych od fałszywych, środki, za pomocą których każde $\mathrm{z}$ nich jest sankcjonowane; techniki i procedury przyzna- 
jące wartość nabywaniu prawdy; status tych osób, których obowiązkiem jest mówienie tego, co liczy się jako prawdziwe" (Foucault 1980: 131).

\section{Podsumowanie}

Celem wystąpień sejmowych nie jest ustalenie prawdy. By jeszcze raz zacytować Foucaulta: „prawda to wizja świata, którą otacza nas władza” (Błaszenowski 2009: 83). Przemawiające osoby działają raczej $\mathrm{w}$ swoim pragmatycznym interesie, jakim jest uzyskanie przychylności wyborców poprzez odwołanie się do emocji i wzbudzanie emocji (to jest często faktyczny cel wystąpień sejmowych). Uczestnicy interakcji paradoksalnie są w tym postępowaniu zaskakująco spójni i dopasowani w swych działaniach. Mamy więc w przedstawieniach sejmowych - aby użyć terminów związanych z perspektywą dramaturgiczną - do czynienia $\mathrm{z}$ ukonstytuowaniem się specyficznej dla świata polityki, tożsamości sytuacyjnej. Tożsamość taka opiera się na roli przyjmowanej i potwierdzanej przez partnerów interakcji. „Tożsamość sytuacyjna istnieje tak długo, jak długo istnieje sytuacja występowania w tej roli” (Hałas, Konecki [red.] 2005: 34).

W toku analizy wyłonił się behawioralny schemat wystąpień oparty na następującej prawidłowości:

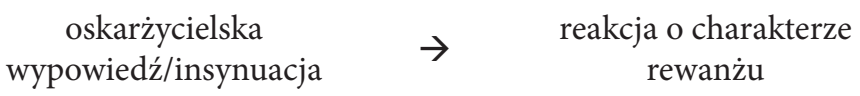

Interakcje nakierowane są na silnie zabarwioną emocjonalnie retorykę opartą na wyszydzeniu/ośmieszeniu, w konsekwencji wywołaniu uczucia wstydu i/lub obronie przed tymi emocjami (riposty w walce o odzyskanie twarzy, poczucie dumy). Sejmowi aktorzy dobrze rozumieją spektakl, w którym przyszło im grać. 
Można dostrzec tu pewien metaprzekaz, czytelny dla działających w tej interakcji jednostek, choć nie jest on otwarcie wyrażany w debatach sejmowych - jest nim gra o własny wizerunek publiczny i wyborcę. Specyficzny charakter tożsamości sytuacyjnej aktorów uczestniczących w przedstawieniach sejmowych opiera się na wzajemnej świadomości dążenia przez każdą ze stron do manipulowania rzeczywistością w celu realizacji własnych politycznych celów. Interakcje w świecie polityki przyjmują formę interakcji strategicznych, w których jedna lub obydwie ze stron interakcji ukrywają intencje swoich działań, by wprowadzić drugą stronę w błąd i osiągnąć określone cele (Konecki 2005: 178). Tożsamość aktorów świata polityki ujawnia swój postmodernistyczny charakter, w którym niestałość, pozorna niespójność celów i sprzeczne wypowiedzi są organicznie związane z grą polityczną.

Retoryka takowa może świadczyć o zwróceniu się polityków w stronę demokracji medialnej, w której główną rolę odgrywa kreowanie przekazu, zaś język, w jakim się komunikują, przekształcony zostaje w narzędzie służące oddziaływaniu na rzeczywistość i jako takie musi być dostosowane do poziomu odbiorcy masowego. Stanisław Michalczuk wymienia cechy charakterystyczne demokracji medialnej:

- „wzrost znaczenia mediów, które odgrywają decydującą rolę $\mathrm{w}$ procesie legitymizacji przez komunikację, nie tylko bowiem tworzą polityczną opinię publiczną, ale też stają się kontrolerem zachodzących procesów;

- wzrost znaczenia form organizacji komunikowania, takich jak public relations, polityki symbolicznej, inscenizacji polityki, tworzenia wydarzeń oraz pseudowydarzeń politycznych i społecznych;

- kariera telewizji jako medium przewodniego, z jej możliwościami wizualizacji, w miejsce komunikacji polityczno-programowej, przy równoczesnej utracie znaczenia przez media drukowane; 
- wzrost znaczenia kompetencji medialnej aktorów politycznych, przy jednoczesnej utracie znaczenia ich kompetencji merytorycznych; inwazja takich form jak talk-show, zastępujących coraz częściej prowadzenie rzetelnych i merytorycznych dyskursów politycznych;

- wzrastająca rola przekazów obrazowych, przez które obywatel postrzega rzeczywistość polityczną" (Michalczuk 2008: 61-62).

W konsekwencji mamy do czynienia z prymitywizacją i upadkiem retoryki oraz skróceniem horyzontu pamięci społecznej, ponieważ w czasach afer i emocjonalnych, głośnych sporów, informacje szybko tracą na swej atrakcyjności, przez co jedne muszą być zastępowane przez drugie, równie emocjonalnie nasycone, w niespotykanym dotąd tempie.

Przemiany współczesnej polityki można również łączyć z koncepcją postpolityki. Andrzej Nowak zjawisko to sprowadza do retorycznego manipulowania i grania na emocjach. Ponadto w opinii A. Nowaka, „postpolityka polega na niestawianiu sobie żadnych celów związanych z dobrem wspólnym [...]" (Kusiak 2011: 173). Natomiast zdaniem politologa Bartłomieja Machnika „W świecie postpolityki emocje zajęły miejsce programów wyborczych, a wizerunek zdystansował idee. W takiej rzeczywistości prym wiodą dobrze przygotowane, profesjonalne opowieści, które omijają banał, są skierowane na emocje, a pomijają idee i programy" (Machnik 2011, http://www.nowapolitologia.pl/ politologia/marketing-polityczny/postpolityka-idee-niewazne-wazna-wladza [dostęp 09.12.2014]. W tym ujęciu prawda nie jest wartością nadrzędną i wcale nie dąży się do jej odkrywania, a tylko podejmuje się starania, by nią odpowiednio manipulować, ponieważ prawdą jest tam to, co zostało za nią uznane (Kusiak 2011: 173), a polityce nałożona zostaje cyniczna maska, której przywdzianie sprawia, że kłamcy nazywają kłamców kłamcami (Szafrański 2009: 168, [za:] Sloterdijk 2008: 4). 


\section{THE POLISH SEJM GAMES}

Abstract. This article is a try of analysis real meanings of parliamental speeches between each speakers. Starting point for this analyze is sociology of emotions by Thomas Scheff and dramaturgic perspective by Erving Goffman which are linked with definition of "face" "performance" and "ridicule". To face up the task I analyze content of speeches presented by Donald Tusk and Witold Waszczykowski.

Key words: sociology of emotions, politics, construction of transmission, shame, face, symbolic interactionism, Erving Goffman, Thomas Scheff.

\section{Bibliografia}

Błaszewski, Bartłomiej (2009), Batalia o człowieka. Genealogia władzy Michela Foucaulta jako próba wyzwolenia podmiotu, Wydawnictwo Uniwersytetu Warszawskiego, Warszawa

Dobek-Ostrowska, Bogusława (2011), Polski system medialny na rozdrożu. Media w polityce, polityka w mediach, Wydawnictwo Uniwersytetu Wrocławskiego, Wrocław

Foucault, Michel (1980), Power/ Knowledge: Selected Interviews and Other Writings, 1972-1977, ed. Colin Gordon, Pantheon, New York

Goffman, Erving (2008), Człowiek $w$ teatrze życia codziennego, Wydawnictwo Aletheia, Warszawa

Goffman, Erving (2006), Rytuat interakcyjny, Wydawnictwo Naukowe PWN, Warszawa

Goffman, Erving (2008), Zachowanie w miejscach publicznych. O spotecznej organizacji wydarzeń,
Wydawnictwo Naukowe PWN, Warszawa

Hałas, Elżbieta (2006), Interakcjonizm symboliczny, Wydawnictwo Naukowe PWN, Warszawa

Hałas, Elżbieta (2005), Jaźń jako interakcja symboliczna a konstrukcjonistyczne koncepcje człowieka późnej nowoczesności, [w:] Elżbieta Hałas, Krzysztof T. Konecki (red.), Konstruowanie jaźni i spoteczeństwa, Wydawnictwo Naukowe SCHOLAR, Warszawa, s. 23-39

Konecki, Krzysztof T. (2005), Ludzie $i$ ich zwierzęta. Interakcjonistyczno-symboliczna analiza spotecznego świata właścicieli zwierząt domowych, Wydawnictwo Naukowe SCHOLAR, Warszawa

Konecki, Krzysztof T. (2007), Nowi pracownicy a kultura organizacyjna przedsiębiorstwa. Studium folkloru fabrycznego, „Przegląd Socjologii Jakościowej", Monografie, t. III, nr 1 
Konecki, Krzysztof T. (2014), Socjologia emocji według Thomasa Scheffa, [w:] Krzysztof T. Konecki, Beata Pawłowska (red.), Emocje w życiu codziennym. Analiza kulturowych, społecznych i organizacyjnych uwarunkowań ujawniania i kierowania emocjami, Wydawnictwo Uniwersytetu Łódzkiego, Łódź, s. 11-38

Konecki, Krzysztof T. (2012), Wizualna teoria ugruntowana. Podstawowe zasady i procedury, „Przegląd Socjologii Jakościowej”, t. 8, nr 1, s. $12-45$

Konecki, Krzysztof T. (2005), Wizualne wyobrażenia. Główne strategie badawcze w socjologii wizualnej a metodologia teorii ugruntowanej, „Przegląd Socjologii Jakościowej”, t. 1, nr 1, s. 42-63

Kusiak, Paweł (2011), Postpolityka. W poszukiwaniu istoty zjawiska, Colloquium Wydziału Nauk Humanistycznych i Społecznych AMW, Gdynia

Machnik, Bartłomiej (2011), Postpolityka - idee nieważne, ważna władza, „Nowa Politologia”, http:// www.nowapolitologia.pl/politologia/marketing-polityczny/postpolityka-idee-niewazne-wazna-wladza [dostęp 09.12.2014]

Michalczyk, Stanisław (2008), Społeczeństwo medialne. Studia z teorii komunikowania masowego, Śląskie Wydawnictwo Naukowe, Katowice

Michałowski, Piotr (2003), Strategie skandalu i stereotypu odbioru, „Przestrzenie Teorii”, $\mathrm{nr} 2$, s. $73-88$
Miłkowska-Samul, Kamila (2013), Emocje a skandal polityczny. o sposobach wykorzystania emocji $w$ dyskursie politycznym, „Przegląd Socjologii Jakościowej”, t. 9, nr 2, s. 164-183

Mistewicz, Eryk (2011), Idee nieważne, ważna władza, „Uwarzamrze”, nr 4, s. 68, [w:] Walecka-Rynduch, Agnieszka (2013), Polityczność, polityka i Pan Nergal w kontekście tabloidyzacji polskiej sceny politycznej, „Środkowoeuropejskie Studia Polityczne", Poznań, nr 1, s. $121-138$

Pawłowski, Marek (2013), Demokracja medialna, „Refleksje”. Pismo naukowe studentów i doktorantów WNPiD UAM, Poznań, nr 8, s. $133-147$

Pietrzyk-Zieniewicz, Ewa (2004), Perswazja - język mediów - ryzyko demagogii, [w:] Ewa Pietrzyk-Zieniewicz (red.), Scena polityczna i media: miraże sukcesu, ryzyko autoprezentacji, Warszawa, s. $11-30$

Sajduk, Błażej (2008), Polityka postpolityki, postpolityka w polityce, Ośrodek Myśli Politycznej, http://www. omp.org.pl/stareomp/index719e. html? module=subjects \&fun c=viewpage\&pageid=722 [dostęp 09.12.2014]

Schopenhauer, Arthur (1973), Erystyka, czyli sztuka prowadzenia sporów, Wydawnictwo Literackie, Kraków

Seklecka, Aleksandra (2011), Polityk w Internecie - między wpływem politycznym a manipulacja opiniq publiczną, [w:] Marek Jeziński 
(red.), Nowe media w systemie komunikowania: polityka, Wydawnictwo Adam Marszałek, Toruń, s. 86-101

Sloterdijk, Peter (2008), Krytyka cynicznego rozumu, Wydawnictwo Naukowe Dolnośląskiej Szkoły Wyższej, Wrocław

\section{Netografia}

Co dalej z szefem MSZ? Dziś głosowanie, http://www.tvpparlament.pl/ aktualnosci/co-dalej-z-szefem-msz-dzis-glosowanie/5912998 [dostęp 30.05.2014]

Donald Tusk, 15.12.2011 r.; 21:57, https://www.youtube.com/watch?

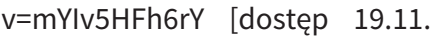
2014]

PiS nie chce poprzeć wniosku SP o wotum nieufności dla Sikorskiego, zgłasza swój... identyczny, http://www. polskatimes.pl/artykul/477975,pis-nie-chce-poprzec-wniosku-sp-o-wotum-nieufnosci-dla-sikorskiego-zglasza-swoj-identyczny,id,t. html?cookie=1 [dostęp 21.11.2014] Sejm: wptynąt wniosek o wotum nieufności dla Sikorskiego, http:// www.wprost.pl/ar/281864/Sejm-wplynal-wniosek-o-wotum-nieufnosci-dla-Sikorskiego/ [dostęp 21.11.2014]
Szafrański, Jakub (2009), Hermeneutyka dyskursu postpolitycznego, Repozytorium „Annales UMCS”, Lublin

Turner, Jonathan H. (2004), Struktura teorii socjologicznej. Wydanie nowe, Wydawnictwo Naukowe PWN, Warszawa

Sikorski chce IV Rzeszy. Niech się spakuje i wróci do Waszyngtonu, http://www.polskatimes.pl/artykul/477415,sikorski-chce-iv-rzeszy-niech-sie-spakuje-i-wroci-do-waszyngtonu,id,t.html [dostęp 21.11.2014]

Sikorski zostaje. Wniosek o wotum nieufności odrzucony, http://wiadomosci.dziennik.pl/polityka/ artykuly/371358,radoslaw-sikorski-zostaje-na-stanowisku-ministra-spraw-zagranicznych.html [dostęp 21.11.2014]

Stownik Języka Polskiego PWN, http://sjp.pwn.pl/szukaj/skandal.html [dostęp 21.11.2014]

Witold Waszczykowski, 15.12.2011r.; 22:23, https://www.youtube.com/ watch?v=ylwUtDlaEWU [dostęp 19.11.2014] 